\title{
MENGUKUR KETERLIBATAN SISWA DALAM PEMBELAJARAN ONLINE SISWA KELAS VII DI SEKOLAH ABC PADA PEMBELAJARAN MATEMATIKA
}

\author{
Gabriel Nababan ${ }^{\text {* }}$, Jun Extin Loyalti Purba ${ }^{2}, K_{\text {Kristina Anugerah Aji }}$ \\ ${ }^{1,2,3}$ Program Studi Teknologi Pendidikan, Program Magister, Universitas Pelita Harapan \\ Jalan Jend. Sudirman No.50, Jakarta 12930, Indonesia \\ e-mail: 1nababan.gabriel03@gmail.com; \\ Submitted: September 06, $2021 \quad$ Revised: November 10, 2021 \\ Accepted: November 16, 2021 \\ corresponding author*
}

\begin{abstract}
Abstrak
Mengembangkan pemahaman tentang apa yang mendasari keterlibatan siswa dalam lingkungan pembelajaran online merupakan hal yang penting, khususnya di masa pandemi Covid-19 yang telah mengharuskan para pelajar mengikuti proses pembelajaran di rumah. Tujuan penelitian ini adalah untuk mengukur keterlibatan siswa kelas VII Sekolah ABC selama pembelajaran online dan menjadi bahan evaluasi untuk proses pembelajaran online. Metode penelitian yang digunakan adalah penelitian kuantitatif dengan tehnik pengumpulan data yang digunakan adalah menggunakan lembar kuesioner online menggunakan skala Likert 1 hingga 5 dan menggunakan Online Student Engagement Scale yang dikembangkan oleh Marcia D. Dixson. Hasil pengolahan data menunjukkan bahwa kuesioner online adalah valid. Berdasarkan hasil analisis uji korelasi menggunakan metode Chi-Square, diperoleh kesimpulan bahwa tidak terdapat korelasi antara keterlibatan siswa dengan asal SD sebelumnya. Sedangkan berdasarkan hasil analisis uji Mean menggunakan uji Z, diperoleh kesimpulan bahwa tidak cukup data untuk membuktikan bahwa terdapat perbedaan rata-rata keterlibatan antara siswa laki-laki dengan keterlibatan siswa perempuan
\end{abstract}

Kata Kunci: keterlibatan siswa, pelajaran matematika, pembelajaran online

\section{MEASURING STUDENT ENGAGEMENT IN ONLINE LEARNING OF CLASS VII STUDENTS AT SEKOLAH ABC IN MATHEMATICS}

\begin{abstract}
An understanding of what students interact with in the learning environment is important, especially during the COVID-19 pandemic which requires students to follow the learning process from home. The purpose of this studi was to measure the student engagement of $7^{\text {th }}$ grade students of ABC School during online learning and to be sn evaluation material for the online learning process. The research method used is qualitative research with data collection techniques used an online questionnaire sheet with Likert Scale of 1 to 5 from Online Student Engagement Scale developed by Marcia D. Dixson. The results of data processing indicate that the online questionnaire is valid. It conclusion, based on the correlation test analysis using the Chi-Square method, there was no correlation between student involvement and previous elementary school origins. Based on the results of the analysis of Mean test using the $\mathrm{Z}$ test, it was concluded that there was not enough data to prove that there was a difference in the average involment of male students with the involvement of female students
\end{abstract}

Keywords: student engagament, math lessons, online learning

\section{Pendahuluan}

Setahun semenjak pandemi COVID-19 melanda Indonesia pada Maret 2020, sistem pelaksanaan pembelajaran di dalam instansi pendidikan, baik sekolah maupun perguruan tinggi harus menyesuaikan dengan situasi dan kondisi yang paling sesuai. Pemerintah telah mewajibkan peserta didik dari semua jenjang pendidikan untuk melakukan pembelajaran dari rumah dengan menggunakan aplikasi-aplikasi yang tersedia. Dengan demikian, proses belajar harus beralih dari 
pembelajaran tatap muka di dalam kelas (face to face) menjadi pembelajaran online. Harapannya, penerapan pembelajaran online menjadi alternatif yang terbaik untuk bisa mengadakan proses pembelajaran yang efektif selama masa pandemi Covid-19 masih berlangsung.

Pembelajaran online telah diterapkan di instansi sekolah, baik dari jenjang TK hingga SMA, dengan mengimplementasikan pembelajaran jarak jauh menggunakan digital untuk mengoptimalkan pembelajaran non tatap muka sekaligus jarak jauh. Adapun model pembelajaran ini dapat diimplementasikan dalam bentuk asynchronous, synchronous atau penggabungan keduanya dan pada tahun ajaran 2020/2021 ini.

Teknik synchronous memberikan peluang bagi pengajar maupun pelajar untuk dapat melakukan tatap muka dan berinteraksi di dalam kelas virtual. Terdapat banyak software atau perangkat lunak yang dapat digunakan untuk melakukan sinkronis. Misalnya Microsoft Teams, Google Meets, Zoom, dan perangkat lunak lainnya yang dilengkapi dengan fitur video call. Pemilihan platform dalam melangsungkan pembelajaran online ini bergantung kepada keputusan sekolah atau kampus masing-masing. Pertimbangan pemilihan bisa berupa kemudahan dalam mengaksesnya, besar kecilnya bandwidth yang digunakan, atau bisa juga karena kelengkapan fiturnya. Sedangkan teknik asynchronous memberikan peluang bagi pengajar dan juga pelajar untuk untuk tidak melakukan pertemuan virtual secara bersama-sama, namun lebih kepada kemudahan untuk mengakses materi atau bahan ajar oleh pelajar yang lebih fleksibel, yakni kapan dan dimana saja.

Pemanfaatan perangkat lunak, perangkat keras serta jaringan internet sebagai media pembelajaran pada masa pembelajaran online ini diharapkan dapat mengupayakan para siswa dapat terlibat di dalam proses pembelajaran walaupun dilakukan secara online. Maka dapat disimpulkan bahwa pembelajaran online dapat menfasilitasi siswa untuk terlibat di dalam pembelajaran walaupun dilakukan di rumah masing-masing, karena keterlibatan siswa adalah kunci dalam mempertahankan siswa terhubung dengan pembelajaran (Dixson, 2015).

Sekolah Swasta ABC di Makassar merupakah salah satu sekolah yang telah menerapkan model pembelajaran online dengan mengimplementasikan sesi asynchronous dan synchronous. Software yang digunakan untuk melakukan sesi asynchronous dan synchronous adalah Microsoft Teams. Peneliti melakukan wawancara terhadap salah satu guru bidang studi Matematika kelas VII di sekolah tersebut. Tujuan dari wawancara ini adalah untuk mengetahui bagaimana kondisi keterlibatan siswa kelas VII dalam pelajaran Matematika dimasa pembelajaran online. Menurut pandangan guru bidang studi berdasarkan hasil observasi, fakta di lapangan yang ditemukan adalah siswa cenderung tidak aktif, partisipasi di dalam kelas online sangat kurang, interaksi siswa selama pembelajaran online cukup rendah, dan siswa kurang mengenal antar satu sama lain. Selain itu beberapa jenis pelanggaran terus terjadi secara konsisten setiap hari, seperti tidak muncul dalam sesi, telat mengumpulkan tugas/projek sesuai tenggang waktu, serta tidak membuka kamera video pada saat sesi synchronous.

Peneliti juga menanyakan kepada guru bidang studi perihal pengadaan asesmen untuk mengukur keterlibatan siswa di pelajaran Matematika. Adapun guru bidang studi belum pernah melakukan pengukuran dan hanya melakukan observasi langsung di dalam kelas online serta mendata masalah-masalah yang sering muncul selama pembelajaran online. Guru bidang studi juga menyampaikan bahwa siswa kelas VII berasal dari SD yang berbeda-beda dan langsung memula tahun ajaran baru dengan model pembelajaran online. Artinya siswa memiliki latar belakang budaya sekolah yang berbeda-beda dan siswa masih berada dalam masa transisi serta penyesuaian, baik terhadap komunitas, budaya sekolah, dan proses pelaksanaan pembelajaran secara online.

Selain itu, dari sudut stereotype gender yang ditemukan pada banyak studi penelitian, dijelaskan bahwa adanya keterkaitan antara bidang teknis dengan Matematika dimana terdapat sebuah persepsi bahwa cara orangtua menyajikan aktivitas terhadap anak laki-laki berbeda dengan anak perempuan. Anak laki-laki cenderung melakukan aktivitas yang berhubungan dengan teknologi dan tindakan seperti pada penggunaan komputer atau perangkat digital. Studi mengenai pentingnya peranan gender yang menjadi salah satu faktor pencapaian nilai pembelajaran digital selama masa pandemi (Korlat et al, 2021).

Berdasarkan data yang telah diperoleh di atas, maka peneliti memutuskan untuk mengukur tingkat keterlibatan siswa untuk tingkat kelas VII pada pelajaran Matematika di masa pembelajaran online. Rumusan masalah yang diangkat dalam penelitian ini adalah: 1) Apakah keterlibatan siswa kelas VII dipengaruhi oleh asal SD sebelumnya? 2) Apakah terdapat perbedaan rata-rata keterlibatan 
siswa laki-laki dengan siswa perempuan? Melalui rumusan masalah ini, maka tujuan penelitian adalah untuk mengetahui ada tidaknya hubungan antara keterlibatan siswa kelas VII dengan asal sekolah sebelumnya dan untuk mengetahui ada tidaknya perbedaan rata-rata keterlibatan siswa berdasarkan gender.

\section{Keterlibatan Siswa}

Menurut Fredricks \& McColskey (2012), keterlibatan siswa didefinisikan sebagai suatu meta-konstruksi yang mencakup keterlibatan perilaku, emosional, dan kognitif. Keterlibatan siswa juga dapat dipandang sebagai salah satu kunci mengatasi masalah seperti prestasi rendah, kebosanan dan keterasingan, dan tingkat putus sekolah yang tinggi. Menurut $\mathrm{Hu}$ dan Kuh (2002, p. 555), keterlibatan merupakan waktu dan energi yang siswa curahkan terhadap kegiatan pendidikan. Menurut Dixson (2015) keterlibatan siswa dalam pembelajaran online adalah waktu dan energi yang siswa curahkan untuk mempelajari materi dan keterampilan, untuk membangun interaksi yang bermakna di dalam kelas, dan menikmati proses pembelajaran. Berdasarkan dua definisi di atas, maka dapat disimpulkan bahwa keterlibatan siswa adalah tentang bagaimana siswa menggunakan waktu, energi, pemikiran, usaha, dan sampai batas tertentu, perasaan mereka ke dalam pembelajaran.

Fredricks, Blumenfeld, \& Paris (2004) dalam Fredricks \& McColskey (2012, p. 763) menyatakan bahwa para peneliti, pengajar, beserta pembuat kebijakan semakin fokus pada keterlibatan siswa sebagai kunci untuk mengatasi masalah pencapaian pelajar yang rendah, tingkat kebosanan yang tinggi, merasa terasing, dan angka putus sekolah yang tinggi.

Menurut Fredricks, Blumenfeld, dan Paris (2004) di dalam Fredricks J. , et al. (2011, p. 2), keterlibatan siswa terdiri dari 3 dimensi utama atau subtype: perilaku (behavioral engagement), kognitif (cognitive engagement), dan emosional (emotional engagement). Keterlibatan perilaku (behavioral engagement) mengacu pada konsistensi upaya, partisipasi, kehadiran, pekerjaan rumah, dan perilaku akademis lain yang diinginkan. Keterlibatan kognitif (cognitive engagement) mengacu pada investasi dalam pembelajaran, kedalaman pemrosesan, dan atau penggunaan strategi metakognitif. Keterlibatan emosional (emotional engagement) mengacu pada pengaruh dan emosi siswa di sekolah, seperti minat, kebosanan, atau kecemasan.

Martin \& Torres (2016) di dalam User's Guide and Toolkit for the Survey of Student Engagement: The High School Survey of Student Engagement (HSSSE) and the Middle Grades Survey of Student Engagement (MGSSE) juga menguraikan keterlibatan siswa dalam 3 dimensi. Ketiga dimensi tersebut adalah keterlibatan perilaku berfokus pada partisipasi dalam akademis, kegiatan sosial, dan kurikuler; keterlibatan emosional berfokus pada tingkat dan sifat reaksi positif dan negatif terhadap guru, teman sekelas, akademisi, dan sekolah; keterlibatan kognitif, fokus pada tingkat investasi siswa dalam belajar.

Berdasarkan National Survey of Student Engagement (NSSE), mengidentifikasi 4 kategori dalam keterlibatan siswa, yakni 1) tingkat akademik (academic challenge), 2) belajar dengan teman sebaya (learning with peers), 3) pengalaman dengan fakultas (experiences with faculty), dan 4) lingkungan kampus (campus environment).

Dixson (2015) menjelaskan 4 faktor keterlibatan dalam pembelajaran online, yaitu keterampilan, emosi, partisipasi, dan kinerja. Keterampilan adalah gaya belajar, seperti belajar secara teratur, mendengarkan dan membaca dengan cermat, atau mencatat. Emosi adalah keadaan perasaan tentang belajar, seperti usaha atau keinginan untuk belajar. Partisipasi adalah perilaku dalam kursus, seperti mengobrol, berdiskusi, atau bercakap-cakap. Kinerja adalah suatu hasil, seperti nilai atau mengerjakan ujian dengan baik. Keempat faktor keterlibatan dalam pembelajaran online ini dikembangkan dari keterlibatan siswa di dalam kelas secara tradisional oleh Handelsman, Briggs, Sullivan, \& Towler (2005).

Penelitian ini berfokus pada faktor keterlibatan dalam pembelajaran online menurut Dixson (2015) karena sesuai dengan kondisi pelaksanaan pembelajaran saat ini yang berlangsung secara online. Indikator keterlibatan siswa yang digunakan adalah skala keterlibatan siswa online atau disebut dengan Online Student Engagement Scale (OSE Scale) yang dikembangkan oleh Dixson dari 4 faktor keterlibatan menurut Handelsman, Briggs, Sullivan, \& Towler (2005). 
Tabel 1. Indikator Keterlibatan Siswa Online (The Online Student Engagement Scale/ OSE)

\begin{tabular}{|c|c|c|c|c|}
\hline Skill & Emotion & & Participation & Performance \\
\hline $\begin{array}{ll}a . & \text { Study regularly } \\
b . & \text { Staying up on reading } \\
c . & \text { Look over class notes } \\
d . & \text { Be organized } \\
e . & \text { Listen/read carefully } \\
f . & \text { Take good notes over } \\
& \text { readings, PPT, Video }\end{array}$ & $\begin{array}{ll}\text { a. } & \text { Put forth effort } \\
\text { b. } & \text { Find ways to make } \\
& \text { materials relevant } \\
\text { c. } & \text { Apply to my life } \\
\text { d. } & \text { Find ways to make } \\
& \text { material interesting } \\
\text { e. } & \text { Really desire to } \\
& \text { learn }\end{array}$ & $\begin{array}{c}c \\
d .\end{array}$ & $\begin{array}{l}\text { Have fun in online } \\
\text { chats, discussions or } \\
\text { via email with the } \\
\text { instructor or other } \\
\text { students } \\
\text { Participate actively } \\
\text { in forums } \\
\text { Help fellow students } \\
\text { Engage in online } \\
\text { conversations } \\
\text { Post regularly in } \\
\text { forum }\end{array}$ & $\begin{array}{ll}\text { a. } & \text { Do well on tests } \\
\text { b. } & \text { Get good grades }\end{array}$ \\
\hline
\end{tabular}

\section{Pembelajaran Online}

Menurut Carliner (2004, p. 1), online learning cenderung kepada pembelajaran dan sumber pendukung lainnya yang dapat diakses melalui sebuah komputer, dimana komputer menampilkan materi sesuai dengan permintaan pelajar, mendorong pelajar untuk memperoleh lebih banyak informasi, dan menyajikan materi yang sesuai berdasarkan tanggapan pelajar. Pembelajaran online juga dapat didefinisikan sebagai pendidikan yang berlangsung melalui Internet. Maka dapat disimpulkan bahwa pembelajaran online merupakan sebuah pendekatan inovatif yang berpusat pada pada peserta didik (student centered) dimana proses pembelajaran berlangsung di dalam jaringan internet dan membutuhkan perangkat keras seperti computer atau gawai untuk menampilkan atau menyajikan informasi kepada pelajar, baik informasi yang dicari oleh pelajar secara mandiri maupun materi yang sudah disediakan oleh pendidik sebelumnya.

Menurut Yuhanna, Alexander, \& Kachik (2020, p. 14), kelebihan pembelajaran online adalah dapat menggunaan media yang beragam, siswa dapat mengakses perpustakaan dan database yang terupdate setiap hari, siswa dapat bertukar pikiran/ide dengan lebih mudah, komunikasi yang lebih nyaman, misalnya menggunakan email, biaya yang lebih murah. Sedangkan keterbatasan daripada pembelajaran online adalah siswa memiliki akses untuk mengambil hasil karya orang lain (plagiarism), informasi yang tersedia terlalu banyak sehingga mempersulit siswa untuk menemukan sumber yang valid, koneksi internet yang buruk, semua pengguna harus terhubung dengan internet dan menggunakan software dan hardware yang up to date, dan siswa harus menjadi pembaca yang kritis dan pemikir dalam mengevaluasi informasi.

\section{Metode Penelitian}

Penelitian ini dilaksanakan di Sekolah Swasta ABC di kota Makasar, Sulawesi Selatan. Populasi yang juga digunakan sebagai sampel penelitian adalah siswa kelas VII yang terdiri dari 4 kelas pararel dengan total siswa sebanyak 94 orang. Pengukuran keterlibatan siswa kelas VII hanya difokuskan pada mata pelajaran Matematika.

Pengumpulan data dilaksanakan pada 30 Maret 2020 sampai 3 April 2021 dengan membagikan kuisioner online kepada siswa. Pemilihan waktu ini berdasarkan pertimbangan bahwa pembelajaran online telah berjalan selama 1 semester. Penggunaan lembar kuesioner online menggunakan skala Likert 1-5 untuk mengakomodasi respon siswa. Skala 1 menunjukkan respon sangat tidak setuju terhada pernyataan (STS), skala 2 menunjukkan kategori tidak setuju (TS), skala 3 kategori netral (N), skala 4 kategori setuju (S), dan skala 5 sebagai kategori sangat setuju (SS). Format kuesioner terdiri dari 25 pernyataan yang disusun berdasarkan skala keterlibatan siswa online (Online Student Engagement Scale) yang dikembangkan oleh Marcia D. Dixson

Tabel 2. Indikator dan Butir-butir pernyataan Kuesioner

\begin{tabular}{llc}
\hline Indikator & Nomor Pertanyaan & $\begin{array}{c}\text { Jumlah } \\
\text { Pernyataan }\end{array}$ \\
\hline Faktor Skills & $1,2,3,4,5,6,7,8$ & 8 \\
\hline $\begin{array}{l}\text { Faktor } \\
\text { Emotion }\end{array}$ & $9,10,11,12,13,14$ & 6 \\
\hline $\begin{array}{l}\text { Faktor } \\
\text { Participation }\end{array}$ & $15,16,17,18,19,20,21$ & 7 \\
\hline $\begin{array}{l}\text { Faktor } \\
\text { Performance }\end{array}$ & $22,23,24,25$ & 4 \\
\hline
\end{tabular}

Validitas merupakan uji tingkat ketepatan suatu instrument untuk mengukur apa yang harus diukur. Validitas berhubungan dengan tingkat 
akurasi dari alat ukur untuk mengukur yang hendak diukur. Langkah-langkah menguji validitas kuesioner adalah sebagai berikut:

a. Menghitung koefisien korelasi menggunakan rumus korelasi momen Pearson:

$$
\mathrm{r}_{x y}=\frac{n \sum_{i=1}^{n} x_{i} y_{i}-\sum_{i=1}^{n} x_{i} \sum_{i=1}^{n} y_{i}}{\sqrt{\left(n \sum_{i=1}^{n} x_{i}^{2}-\left(\sum_{i=1}^{n} x_{i}\right)^{2}\right)\left(n \sum_{i=1}^{n} y_{i}^{2}-\left(\sum_{i=1}^{n} y_{i}\right)^{2}\right)}}
$$

b. Menghitung nilai koefisien validitas instrument yang diuji $\left(\mathrm{r}_{\text {hitung }}\right)$ yang nilainya sama dengan korelasi korelasi hasil langkahlangkah dikalikan dengan koefisien validitas instrument terstandar.

c. Membandingkan nilai koefisien hasil langkah-langkah dengan nilai koefisien korelasi Pearson/ tabel Pearson ( $\mathrm{r}_{\text {tabel }}$ ) pada taraf signifikan $\alpha$ (biasanya dipilih 0,05 ) dan $\mathrm{n}=$ banyaknya data yang sesuai.

d. Tentukan kategori dari validitas instrumen yang mengacu pada pengklasifikasian validitas yang dikemukakan Guilford.

Realibilitas adalah tingkat ketepatan suatu instrument mengukur apa yang harus diukur. Uji reliabitas menggunakan uji Alfa Cronbach dengan rumus sebagai berikut:

$$
\begin{gathered}
\chi_{H}^{2}=\sum_{i=1}^{k} \frac{\left(o_{i}-e_{i}\right)^{2}}{e_{i}} \\
D F=(r-1)(c-1)
\end{gathered}
$$

Uji korelasi adalah Teknik analisis dalam statistic yang digunakan untuk mencari hubungan antara dua variable yang bersifat kuantitatif. Adanya hubungan antara dua variable apabila ada hubungan sebab akibat. Uji korelasi dalam penelitian ini menggunakan Pearson Chi-Square

$$
r=\frac{n}{n-1}\left(1-\frac{\sum \sigma_{i}^{2}}{\sigma^{2}}\right)
$$

Karena variable yang diuji adalah data nonparametrik. Rumus Chi-Square hitung dan ChiSquare tabel secara berurutan adalah sebagai berikut:

$$
Z_{H}=\frac{\left(\overline{X_{1}}-\overline{X_{2}}\right)-\left(\mu_{1}-\mu_{2}\right)}{\sigma_{\overline{X_{1}}-\overline{X_{2}}}}
$$

$\mathrm{H}_{0}$ ditolak atau $\mathrm{H}_{1}$ diterima apabila Chi-Square hitung $\geq$ Chi-Square tabel. Sedangkan HO diterima atau H1 ditolak apabila Chi-Square hitung $\leq$ ChiSquare tabel.

Uji mean adalah Teknik analisis dalam statistika yang digunakan untuk mencari nilai ratarata data. Dalam penelitian ini, data akan dikelompokkan menjadi 2 berdasarkan gender, yakni data laki-laki dan perempuan. Uji mean menggunakan rumus mean data 2 kelompok dengan jumlah responden lebih dari 30 , yakni sebagai berikut:

Penelitian ini hanya memiliki satu jenis variable. Hipotesis yang ditetapkan dalam penelitian ini adalah sebagai berikut:

Hipotesis 1

$\mathrm{H}_{0} \quad$ : Tidak terdapat hubungan antara keterlibatan siswa yang berasal dari SD Sekolah ABC dengan siswa yang berasal dari luar Sekolah ABC.

H1 : Terdapat hubungan antara keterlibatan siswa yang berasal dari SD Sekolah ABC dengan siswa yang berasal dari luar Sekolah ABC.

\section{Hipotesis 2}

$\mathrm{H}_{0}$ : Tidak terdapat perbedaan rata-rata keterlibatan pada siswa laki-laki dengan siswa perempuan

$\mathrm{H}_{1} \quad$ : Terdapat perbedaan rata-rata keterlibatan pada siswa laki-laki dengan siswa perempuan

\section{Hasil dan Pembahasan}

Dari hasil pengumpulan data yang telah dilakukan terhadap siswa kelas VII berjumlah 94 siswa, maka dilakukan uji validitas kuesioner online yang bertujuan untuk meningkatkan tingkat akurasi dari kuesioner online yang digunakan. Sebuah instrument penelitian dapat dikatakan valid jika $r_{x y} \geq r_{a b e l}$. Dengan jumlah responden sebanyak 94 orang, dapat ditarik kesimpulan bahwa instrument yang digunakan adalah valid karena $r_{x y}$ lebih besar dari koefisien $\mathrm{r}_{\text {tabel }}(0,20)$ yaitu 0.81 , $0.80,0.85$, dan 0.59 (lihat tabel 3). Data hasil analisis uji validitas per pernyataan kuisioner online diperoleh seluruh pernyataan adalah valid karena nilai koefisien korelasi hitung lebih besar dari nilai koefisien korelasi tabel $(0,20)$. Hasil analisis uji validitas per pernyataan pada kuesioner online dapat dilihat pada tabel 4 
Tabel 3. Hasil uji validitas kuesioner keterlibatan siswa pada pembelajaran online per indicator

\begin{tabular}{cccc}
\hline Indikator & r hitung & r tabel & Validitas \\
\hline Faktor Skills & 0.81 & 0.20 & 1 \\
Faktor Emotion & 0.80 & 0.20 & 1 \\
Faktor Participation & 0.85 & 0.20 & 1 \\
Faktor Performance & 0.59 & 0.20 & 1 \\
\hline
\end{tabular}

Tabel 4. Hasil uji validitas kuesioner keterlibatan siswa pembelajaran online per butir pernyataan

\begin{tabular}{|c|c|c|c|c|c|}
\hline Indikator & Sub-Indikator & Pernyataan & $\begin{array}{c}\mathbf{r} \\
\text { hitung }\end{array}$ & $\begin{array}{c}\mathbf{r} \\
\text { tabel }\end{array}$ & Validitas \\
\hline \multirow{8}{*}{$\underset{\frac{\pi}{\pi}}{\tilde{\pi}}$} & Study regularly & $\begin{array}{l}\text { Saya mempersiapkan diri untuk belajar } \\
\text { teratur selama pembelajarann online }\end{array}$ & 0.64 & 0.20 & 1 \\
\hline & $\begin{array}{l}\text { Staying up on } \\
\quad \text { reading }\end{array}$ & $\begin{array}{l}\text { Saya membaca bacaan yang telah } \\
\text { diberikan oleh guru, baik pada saat } \\
\text { asyncronus maupun syncronus }\end{array}$ & 0.55 & 0.20 & 1 \\
\hline & $\begin{array}{l}\text { Look over class } \\
\text { notes }\end{array}$ & $\begin{array}{c}\text { Saya tetap melihat catatan pada saat } \\
\text { online untuk memastikan saya } \\
\text { memahami materi }\end{array}$ & 0.75 & 0.20 & 1 \\
\hline & Be organized & $\begin{array}{c}\text { Saya tetap menggunakan buku agenda } \\
\text { untuk menulis due date tugas, jadwal } \\
\text { ulangan, dan lain sebagainya }\end{array}$ & 0.64 & 0.20 & 1 \\
\hline & $\begin{array}{l}\text { Listen/ read } \\
\text { carefully }\end{array}$ & $\begin{array}{l}\text { Saya mendengarkan guru dengan baik } \\
\text { dalam pembelajaran online }\end{array}$ & 0.54 & 0.20 & 1 \\
\hline & & Saya membaca instruksi dan bahan ajar & 0.48 & 0.20 & 1 \\
\hline & $\begin{array}{c}\text { Take good notes } \\
\text { over readings, } P P T \\
\text { video lectures }\end{array}$ & $\begin{array}{l}\text { Saya mencatat bacaan, powerpoin, } \\
\text { video ceramah, atau penjelasan secara } \\
\text { syncronus }\end{array}$ & 0.70 & 0.20 & 1 \\
\hline & & $\begin{array}{l}\text { Saya mencatat bacaan, powerpoin, } \\
\text { video ceramah, atau penjelasan secara }\end{array}$ & 0.76 & 0.20 & 1 \\
\hline \multirow{6}{*}{ 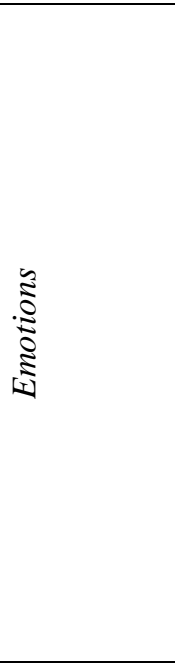 } & Put forth effort & $\begin{array}{l}\text { Saya berusaha untuk menyelesaikan } \\
\text { tugas yang diberikan sesuai due date } \\
\text { atau sebelum due date yang diberikan }\end{array}$ & 0.49 & 0.20 & 1 \\
\hline & & $\begin{array}{c}\text { Saya fokus untuk mendengarkan } \\
\text { instruksi guru dalam pembelajaran } \\
\text { online, baik sesi synchronus maupun } \\
\text { asynchronous }\end{array}$ & 0.66 & 0.20 & 1 \\
\hline & $\begin{array}{l}\text { Find ways to make } \\
\text { materials relevant }\end{array}$ & $\begin{array}{c}\text { Saya menemukan cara agar materi } \\
\text { pembelajaran dapat relevan dengan } \\
\text { kehidupan saya } \\
\end{array}$ & 0.68 & 0.20 & 1 \\
\hline & Apply to my life & $\begin{array}{c}\text { Materi pelajaran dapat saya terapkan } \\
\text { dalam kehidupan sehari-hari }\end{array}$ & 0.71 & 0.20 & 1 \\
\hline & $\begin{array}{l}\text { Find ways to make } \\
\text { material interesting }\end{array}$ & $\begin{array}{c}\text { Saya dapat menemukan cara agar materi } \\
\text { pelajaran dapat menarik bagi saya }\end{array}$ & 0.72 & 0.20 & 1 \\
\hline & $\begin{array}{l}\text { Really desire to } \\
\text { learn }\end{array}$ & $\begin{array}{c}\text { Saya benar-benar ingin belajar dalam } \\
\text { pembelajaran online ini }\end{array}$ & 0.63 & 0.20 & 1 \\
\hline \multirow{4}{*}{ 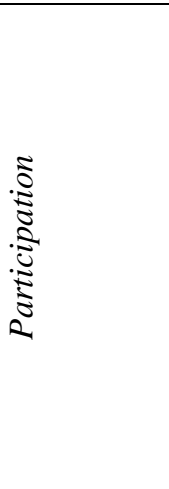 } & $\begin{array}{l}\text { Have fun in online } \\
\text { chats, discussions } \\
\text { or via email with } \\
\text { the instructor or }\end{array}$ & $\begin{array}{c}\text { Saya senang dan menikmati dalam } \\
\text { mengirimkan chats atau diskusi online } \\
\text { atau posting komentar atau mengirim } \\
\text { email dengan guru }\end{array}$ & 0.67 & 0.20 & 1 \\
\hline & other students & $\begin{array}{l}\text { Saya senang dan menikmati dalam } \\
\text { mangirimkan chats atau diskusi online } \\
\text { atau posting komentar atau mengirim } \\
\text { email dengan teman sekelas }\end{array}$ & 0.76 & 0.20 & 1 \\
\hline & $\begin{array}{l}\text { Participate actively } \\
\text { in forums }\end{array}$ & $\begin{array}{l}\text { Saya aktif dalam forum diskusi } \\
\text { kelompok kecil }\end{array}$ & 0.71 & 0.20 & 1 \\
\hline & $\begin{array}{l}\text { Help fellow } \\
\text { students }\end{array}$ & $\begin{array}{l}\text { Saya membantu teman saya selama } \\
\text { pembelajaran online }\end{array}$ & 0.66 & 0.20 & 1 \\
\hline
\end{tabular}




\begin{tabular}{|c|c|c|c|c|c|}
\hline & $\begin{array}{l}\text { Engage in online } \\
\text { conversations }\end{array}$ & $\begin{array}{l}\text { Saya terlibat dalam percakapan online } \\
\text { (chat, video call, email) }\end{array}$ & 0.73 & 0.20 & 1 \\
\hline & $\begin{array}{l}\text { Post regularly in } \\
\text { forum }\end{array}$ & $\begin{array}{c}\text { Saya memposting pendapat atau } \\
\text { tanggapan saya di dalam forum diskusi } \\
\text { secara teratur }\end{array}$ & 0.60 & 0.20 & 1 \\
\hline & $\begin{array}{l}\text { Get to know other } \\
\text { student }\end{array}$ & $\begin{array}{l}\text { Saya mengenal teman-teman saya di } \\
\text { dalam kelas }\end{array}$ & 0.59 & 0.20 & 1 \\
\hline \multirow{4}{*}{ 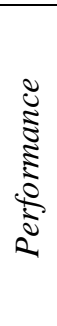 } & Do well on tests & $\begin{array}{c}\text { Saya mengerjakan sumatif sesuai } \\
\text { dengan instruksi yang diberikan guru }\end{array}$ & 0.57 & 0.20 & 1 \\
\hline & & $\begin{array}{c}\text { Saya mengerjakan formatif sesuai } \\
\text { dengan instruksi yang diberikan guru }\end{array}$ & 0.60 & 0.20 & 1 \\
\hline & \multirow[t]{2}{*}{ Get good grades } & $\begin{array}{c}\text { Saya berhasil memperoleh nilai rata-rata } \\
\text { ulangan formatif minimal D }\end{array}$ & 0.81 & 0.20 & 1 \\
\hline & & $\begin{array}{c}\text { Saya berhasil memperoleh nilai rata-rata } \\
\text { ulangan sumatif minimal } 70\end{array}$ & 0.72 & 0.20 & 1 \\
\hline
\end{tabular}

Uji reliabilitas yang digunakan dalam penelitian ini adalah menggunakan rumus Alpha Cronbach. Sebuah instrumen penelitian dikatakan memiliki reliabilitas yang tinggi jika nilai Alpha Cronbach mendekati angka 1 dan dikatakan cukup jika nilai Alpha Cronbach $\geq 0,7$.

Skala standar reliabilitas yang digunakan dalam membandingkan nilai Alpha Cronbach yang diperoleh adalah menggunakan skala kriteria Guilford, yaitu koefisien $\alpha$ dari 0.91 - 1.00 adalah tingkat reliabilitas sangat tinggi, $0.71-0.90$ adalah reliabilitas tinggi, $0.41-0.70$ adalah reliabilitas cukup, $0.21-0.40$ adalah reliabilitas rendah, serta negative -0.20 adalah reliabilitas sangat rendah.

Tabel 5 menunjukkan hasil reliabilitas instrumen memiliki reliabilitas kategori tinggi, yakni nilai $\alpha-0.76$. maka dapat disimpulkan bahwa lembar kuesioner online mengukur keterlibatan siswa pada pembelajaran online dalam penelitian ini memiliki tingkat reliabilitas yang tinggi.

Tabel 5. Hasil uji reliabilitas kuesioner keterlibatan siswa pada pembelajaran online per indicator

\begin{tabular}{ccc}
\hline Indikator & Varians & $\begin{array}{c}\text { Alpha Cronbach } \\
(\alpha)\end{array}$ \\
\hline Skills & 20.26 & \\
Emotion & 12.73 & 0.76 \\
\end{tabular}

\begin{tabular}{lcc} 
Participation & 19.27 & (kategori tinggi) \\
Performance & 0.59 & \\
\hline
\end{tabular}

Penggunaan statistik parametrik dan nonparamterik bergantung pada asumsi dan jenis data yang akan dianalisis. Statistik parametrik memerlukan asumsi bahwa data yang akan dianalisis harus berdistribusi normal dan statistik non-parametrik tidak menuntut data yang akan dianalisis harus berdistribusi normal (Sugiyono,2019, p.209). Pengujian normalitas data pada data laki-laki dilakukan dengan menggunakan uji Chi-Square. Data dapat dikatakan berdistribusi normal jika nilai Chi-Square hitung lebih kecil dari nilai Chi-Square tabel.

Pada uji normalitas data pada responden laki-laki, nilai minimal responden adalah 55, nilai maksimal responden adalah 119 , nilai rata-rata adalah 92.62, dan standar deviasi sama dengan 13.55. Dengan menggunakan angka 15 sebagai interval kelas, maka diperoleh $\mathrm{X}^{2}$ hitung $=4.16$ dan $\mathrm{X}^{2}$ tabel $=11.14$ dengan tingkat kepercayaan $97.5 \%$. Berdasarkan hasil uji normalitas data yang ditunjukkan dalam tabel, diatas dengan membandingkan nilai $\mathrm{X}^{2}$ hitung dengan $\mathrm{X}^{2}$ tabel, maka diperoleh hasil bahwa data responden lakilaki berdistribusi normal karena nilai $\mathrm{X}^{2}$ hitung < $\mathrm{X}^{2}$ tabel.

Tabel 6. Hasil uji normalitas kuesioner keterlibatan siswa data laki-laki

\begin{tabular}{ccccccccc}
\hline Kelas & Xd & Xu & FreqObs & Zdw & Zup & Prob & Fexp & Error \\
& & & & & & & & \\
\hline 1 & 55 & 70 & 1 & -2.81 & -1.633 & 0.05 & 2.1945 & 0.650192 \\
2 & 71 & 86 & 17 & -1.63 & -0.452 & 0.2744 & 12.349 & 1.751462 \\
3 & 87 & 102 & 15 & -0.45 & 0.729 & 0.4414 & 19.865 & 1.191353 \\
4 & 103 & 118 & 10 & 0.73 & 1.911 & 0.2049 & 9.22 & 0.065991 \\
5 & 119 & 134 & 2 & 1.91 & 3.092 & 0.027 & 1.2168 & 0.504151 \\
& TOTAL & & 45 & & & & & 4.16315 \\
& & & & & & & \\
& & & & & & & & 11.14329 \\
\hline
\end{tabular}


Tabel 7. Hasil distribusi normal laki-laki

\begin{tabular}{cc}
\hline $\mathrm{X}^{2}$ hitung & 4.16315 \\
$\mathrm{X}^{2}$ tabel & 11.14329 \\
\hline $\mathrm{X}^{2}$ hitung $<\mathrm{X}^{2}$ tabel (Data berdistribusi Normal) \\
\hline
\end{tabular}

Pada uji normalitas data pada perempuan, nilai minimal responden adalah 66 , nilai maksimal responden adalah 107, nilai rata-rata adalah 90.9, dan standar deviasi sama dengan 9.58. Dengan menggunakan angka 9 sebagai interval kelas, maka diperoleh $\mathrm{X}^{2}$ hitung $=3$ dan $\mathrm{X}^{2}$ tabel $=11.14$ dengan tingkat kepercayaan $97.5 \%$. Dengan membandingkan nilai $\mathrm{X}^{2}$ hitung dengan $\mathrm{X}^{2}$ tabel, maka diperoleh hasil bahwa data responden perempuan berdistribusi normal karena nilai $\mathrm{X}^{2}$ hitung $<\mathrm{X}^{2}$ tabel

Tabel 8. Hasil uji normalitas kuesioner keterlibatan siswa data perempuan

\begin{tabular}{|c|c|c|c|c|c|c|c|c|}
\hline Kelas & Xd & $\mathbf{X u}$ & $\begin{array}{c}\text { Freq } \\
\text { Obs }\end{array}$ & Zdw & Zup & Prob & Fexp & Error \\
\hline $\begin{array}{l}1 \\
2 \\
3 \\
4 \\
5\end{array}$ & $\begin{array}{c}66 \\
76 \\
86 \\
96 \\
106 \\
\text { TOTAL }\end{array}$ & $\begin{array}{c}70 \\
85 \\
95 \\
105 \\
115\end{array}$ & $\begin{array}{c}4 \\
8 \\
18 \\
16 \\
3 \\
49\end{array}$ & $\begin{array}{c}-2.65 \\
-1.61 \\
-0.56 \\
0.48 \\
1.52 \\
\\
X^{2} \text { Tabel }\end{array}$ & $\begin{array}{c}-1.613 \\
-0.56 \\
0.48 \\
1.52 \\
2.57\end{array}$ & $\begin{array}{l}0.05 \\
0.23 \\
0.40 \\
0.25 \\
0.06\end{array}$ & $\begin{array}{c}2.45 \\
11.40 \\
19.50 \\
12.34 \\
2.87\end{array}$ & $\begin{array}{c}0.98 \\
1.01 \\
0.12 \\
1.09 \\
0.01 \\
3.20 \\
11.14\end{array}$ \\
\hline
\end{tabular}

Tabel 9. Hasil distribusi normal perempuan

\begin{tabular}{cc}
\hline $\mathrm{X}^{2}$ hitung & 3.20 \\
$\mathrm{X}^{2}$ tabel & 11.14 \\
\hline $\mathrm{X}^{2}$ hitung $<\mathrm{X}^{2}$ tabel (Data berdistribusi Normal) \\
\hline
\end{tabular}

Metode Chi-Square digunakan untuk pengujian hipotesis ada tidaknya hubungan antara tingkat keterlibatan siswa dengan asal SD sebelumnya. Adapun data dikelompokkan menjadi dua kelompok, yakni siswa dengan asal SD sebelumnya adalah SD ABC dengan siswa dengan SD sebelumnya adalah bukan SD ABC. Siswa dari SD ABC diberikan label angka 0 dan siswa dari luar SD ABC diberi label angka 1. Keseluruhan total nilai kuesioner dari seluruh responden dikelompokkan ke dalam 4 kelas, yaitu kelas 1 (5570 poin), kelas 2 (71-86 poin), kelas3 (87-102 poin), dan kelas 4 (103-119 poin). Tabulasi berdasarkan data observasi ditunjukkan pada tabel 12, tabulasi berdasarkan data ekspektasi pada tabel 13, dan tabulasi data berdasarkan Chi-Square error pada tabel 14 .

Tabel 10. Data observasi

\begin{tabular}{cccc}
\hline \multirow{2}{*}{ Kategori } & \multicolumn{2}{c}{ Asal SD } & \multirow{2}{*}{ Total } \\
\cline { 2 - 3 } & 0 & 1 & \\
\hline 1 & 2 & 0 & 2 \\
\hline 2 & 12 & 19 & 31 \\
\hline 3 & 24 & 22 & 46 \\
\hline 4 & 7 & 8 & 15 \\
\hline Total & 45 & 49 & 94 \\
\hline
\end{tabular}

Tabel 11. Data ekspektasi

\begin{tabular}{cccc}
\hline \multirow{2}{*}{ Kategori } & \multicolumn{2}{c}{ Asal SD } & \multirow{2}{*}{ Total } \\
\cline { 2 - 3 } & 0 & 1 & \\
\hline 1 & 0.96 & 1.04 & 2 \\
\hline 2 & 14.84 & 16.16 & 31 \\
\hline
\end{tabular}

\begin{tabular}{cccc}
\hline 3 & 22.02 & 23.98 & 46 \\
\hline 4 & 7.18 & 7.82 & 15 \\
\hline Total & 45 & 49 & 94 \\
\hline
\end{tabular}

Tabel 12. Data chi-square error

\begin{tabular}{cccc}
\hline \multirow{2}{*}{ Kategori } & \multicolumn{2}{c}{ Asal SD } & \multirow{2}{*}{ Total } \\
\cline { 2 - 3 } & 0 & 1 & \\
\hline 1 & 1.14 & 1.04 & 2.18 \\
\hline 2 & 0.54 & 0.50 & 1.04 \\
\hline 3 & 0.18 & 0.16 & 0.34 \\
\hline 4 & 0.00 & 0.00 & 0.01 \\
\hline Total & 1.86 & 1.71 & 3.57 \\
\hline
\end{tabular}

Tabel 13. Data korelasi two-tails test

$\begin{array}{cc}\mathrm{X}^{2} \text { hitung di kanan } & 9.35 \\ \mathrm{X}^{2} \text { tabel di kiri } & 0.2\end{array}$

Dari keempat tabel di atas, maka diperoleh $\mathrm{X}^{2}$ hitung $=3.57$ dan $\mathrm{X}^{2}$ tabel $=9.35$ untuk daerah tabel sebelah kanan dan $X^{2}$ tabel untuk daerah tabel sebelah kiri adalah 0.2. dari hasil perhitungan dan uji hipotesis korelasi, karena nilai $\mathrm{X}^{2}$ hitung tidak berada pada daerah $\mathrm{X}^{2}$ tabel, maka dapat disimpulkan bahwa tidak terdapat korelasi antara keterlibatan siswa yang berasal dari SD $\mathrm{ABC}$ dengan siswa yang tidak berasal dari SD ABC. Berdasarkan kesimpulan ini, maka tingkat keterlibatan siswa kelas VII di mata pelajaran Matematika tidak dipengaruhi atau tidak memiliki hubungan dengan asal sekolah sebelumnya.

Uji mean dimaksudkan untuk menguji ada atau tidaknya perbedaan rata-rata antara dua kelompok populasi. Sebelum dilakukan uji mean, maka dilakukan pengujian normalitas data. Penggunaan statistic parametrik dan non-parametrik tergantung pada asumsi dan jenis data yang akan dianalisis. Statistik parametrik memerlukan asumsi bahwa data yang dianalis harus 
berdistribusi normal. Sedangkan statistic nonparametrik tidak menuntut data yang akan dianalisis harus berdistribusi normal (Sugiyono, 2019, p. 209). Data dapat dikatakan berdistribusi normal jika nilai $\mathrm{Chi}$ -
Square hitung (X²hitung) lebih kecil dari bilai ChiSquare tabel (X $\mathrm{X}^{2}$ tabel). Oleh karena jumlah responden lebih dari 30 orang, maka uji mean yang digunakan adalah membandingkan nilai Zhitung dan nilai Ztabel.

Tabel 14. Hasil uji mean menggunakan rumus uji $\mathrm{Z}$

\begin{tabular}{cccccc}
\hline Responden & Mean & Stdev & $\mathbf{n}$ & Sp $^{2}$ & Sp \\
\hline Responden Laki-laki & 92.62 & 13.55 & 45 & 134.642 & 11.647 \\
Responden Perempuan & 90.90 & 9.58 & 49 & & \\
TOTAL & & & 94 & & \\
Zhitung & & & \pm .71 & \\
Ztabel (0.975) & & & & \\
\hline
\end{tabular}

Adapun data dikelompokkan menjadi dua kelompok besar, yakni siswa laki-laki dengan jumlah 45 orang dan siswa perempuan dengan jumlah 49 orang. Berdasarkan hasil uji normalitas data siswa laki-laki dan data perempuan, diperoleh keduanya berdistribusi normal karena nilai Chi-Square hitung lebih kecil dari nilai Chi-Square tabel. Maka dapat disimpulkan data akan dianalisis menggunakan statistik parametrik.

Dari hasil pengujian di atas, dapat disimpulkan bahwa $\mathrm{H}_{0}$ diterima dimana tidak cukup data untuk membuktikan bahwa tidak ada terdapat perbedaan ratarata keterlibatan antara siswa laki-laki dengan keterlibatan siswa perempuan. Maka dapat dikatakan bahwa tingkat keterlibatan siswa laki-laki dan siswa perempuan kelas VII dalam pelajaran Matematika selama pembelajaran online berlangsung cenderung sama.

\section{Kesimpulan}

Berdasarkan hasil analisis data dan pembahasannya, peneliti dapat menarik kesimpulan mengenai mengukur keterlibatan siswa dalam pembelajaran online kelas VII di Sekolah ABC pada pelajaran Matematika, yakni sebagai berikut:

a. Hipotesis pertama berdasarkan hasil uji ChiSquare menunjukkan tidak terdapat korelasi antara keterlibatan siswa yang berasal dari SD $\mathrm{ABC}$ dengan siswa yang tidak berasal dari SD ABC.

b. Hipotesis kedua berdasarkan uji Mean menggunakan uji $\mathrm{Z}$ menunjukkan tidak cukup data untuk menunjukkan adanya perbedaan rata-rata keterlibatan antara siswa laki-laki dengan siswa perempuan.

Penelitian ini memiliki keterbatasan dimana proses pengumpulan data hanya dilakukan siswa kelas VII saja. Saran yang dapat diberikan untuk peneliti selanjutnya adalah peneliti dapat membandingkan hasil penelitian ini dengan hasil pengukuran keterlibatan siswa kelas VII di sekolah lain yang menerapkan pembelajaran online yang sama. Tujuannya agar peneliti dapat melihat kelebihan yang dimiliki sekolah lain dalam meningkatkan atau mempertahankan keterlibatan siswa selama pembelajaran online. Selain itu, peneliti selanjutnya juga dapat menambahkan jumlah instrumen untuk mengukur tingkat keterlibatan siswa di masa pembelajaran online untuk memperkaya sumber informasi.

\section{Daftar Pustaka}

Carliner, S. (2004). An Overview of Online Learning. United States: HRD Press, Inc.

Dixson, M. D. (2015). Measuring Student Engagement in the Online Course: The Online Student Engagement Scale (OSE). Online Learning Volume 19 Issue 4 .

Fredricks, J. A., \& McColskey, W. (2012). The Measurement of Student Engagement: A Comparative Analysis of Various Methods and Student Self -report Instruments. Handbook of Research on Student Engagement, 763 - 782.

Fredricks, J.A., Blumenfeld, P., \& Paris, A.H. (2004). School Engagement: Potential of the Concept, State of the Evidence. Review of Educational Research, 74, 109 - 59.

Fredricks, J., McColskey, W., Meli, J., Mordica, J., Montrosse, B., \& Mooney, K. (2011). Measuring student engagement in upper elementary through high school: a description of 21 instruments. REL 2011-No.098, 1-80.

Handelsman, M. M., Briggs , W. L., Sullivan, N., \& Towler, A. (2005). A measure of College Student Course Engagement. The Journal of Educational Research Vol. 98 (No. 3), 184-191.

Hu, S., \& Kuh, G. (2002). Being (Dis)Engaged in Educationally Purposeful Activities: The Influences of Student and Institutional Characteristics. Research in Higher Education 43, 555-575. Retrieved from https://doi.org/10.1023/A:1020114231387

Korlat, S., Kollmayer, M., Holzer, J., Luftenegger, M., Pelikan, E. R., Schober, B., \& Spiel, C. (March 2021). Gender Differences in Digital Learning During Covid-19: Competenece Beliefs, Intrinsic Value, Learning Engagement, and 
Perceived Teacher Support. Frontiers in Psychology Volume 12, 1-12. doi:https://doi.org/10.3389/fpsyg.2021.637776

Martin, J., \& Torres, A. (2016). User's Guide and Toolkit for the Surveys of Student Engagement: The High School Survey of Student Engagement (HSSSE) and the Middle Grades Survey of Student Engagement (MGSSE). Retrieved from National Association of Independent School:
https://www.nais.org/Articles/Documents/Mem ber/2016\%20HSSSE-report-full-FINAL.pdf Sugiyono, P. D. (2019). Metode Penelitian Kuantitatif, Kualitatif dan R\&D. Bandung: Alfabeta.

Yuhanna, I., Alexander, A., \& Kachik, A. (2020). Advantages and Disadvantages of Online Learning. Journal Educational Verkenning, 1319 